\title{
KEMAMPUAN MENULIS NARASI DIKAITKAN DENGAN SIKAP BAHASA DAN PENGETAHUAN EJAAN BAHASA INDONESIA (EBI) DI KELAS V SD NEGERI SERANG 5 KOTA SERANG
}

\author{
Asep Muhyidin \\ FKIP Universitas Sultan Ageng Tirtayasa \\ muhyidin21@gmail.com
}

\begin{abstract}
This study aims to determine empirically the relationship of language attitudes and knowledge of Indonesian spelling (EBI) with writing narrative competence in class V SDN Serang 5 Serang City. The study was conducted on the students of class $V$ of the odd semester of the academic year 2016/2017. The research method used in this research is survey method with correlational study approach. The population of this study is all students of class V SDN Serang 5 Serang City which amounted to 44 students. The data collection in this study is to use test instruments and questionnaires. Based on the results of research and discussion, can be drawn conclusion on the results of research as follows: 1) there is a positive and significant relationship between language attitudes with writing narrative competence; 2) there is a positive and significant relationship between knowledge of Indonesian spelling (EBI) with writing narrative competence, and 3) there is a positive and significant relationship between language attitudes and knowledge of Indonesian spelling (EBI) together with writing narrative competence.
\end{abstract}

Keywords; Writing narrative competence, language attitudes, and Knowledge of Indonesian spelling (EBI)

\section{ABSTRAK}

Penelitian ini bertujuan untuk mengetahui secara empiris hubungan antara sikap bahasa dan pengetahuan Ejaan Bahasa Indonesia (EBI) dengan kompetensi menulis narasi di kelas V SDN Serang 5 Kota Serang. Penelitian ini dilakukan terhadap siswa kelas V semester ganjil tahun akademik 2016/2017. Metode penelitian yang digunakan dalam penelitian ini adalah metode survei dengan pendekatan studi korelasional. Populasi dalam penelitian ini adalah seluruh siswa kelas V SDN Serang 5 Kota Serang yang berjumlah 44 siswa. Pengumpulan data dalam penelitian ini adalah menggunakan alat uji dan kuesioner. Berdasarkan hasil penelitian dan pembahasan, dapat ditarik kesimpulan hasil penelitian sebagai berikut: 1) Ada hubungan positif dan signifikan antara sikap bahasa 
dengan kompetensi naratif menulis siswa; 2) Ada hubungan positif dan signifikan antara pengetahuan tentang ejaan bahasa Indonesia (EBI) dengan kompetensi menulis naratif, dan 3) ada hubungan positif dan signifikan antara sikap bahasa dan pengetahuan tentang ejaan bahasa Indonesia (EBI) bersamaan dengan menulis naratif.

Kata kunci: Kompetensi Menulis Naratif, Sikap Bahasa, dan Pengetahuan Ejaan Bahasa Indonesia (EBI)

\section{A. PENDAHULUAN}

Pembelajaran bahasa Indonesia menyangkut empat aspek keterampilan berbahasa yaitu keterampilam menyimak, membaca, berbicara dan menulis. Keempat aspek keterampilan berbahasa tersebut pada kenyataannya berkaitan erat satu sama lain, saling menunjang, saling mendukung,, saling bergantung, saling berhubungan sehingga dinamakan catur tunggal. Setiap keterampilan itu juga berkaitan dengan proses berpikir. Semakin baik kemampuan bahasa seseorang semakin baik pula cara berpikirnya. Demikian pula dapat dikatakan semakin baik cara seseorang dalam berpikir tidak terlepas dari kemampuan berbahasanya. Keterampilan berbahasa sangat menunjang dalam proses pembelajaran di sekolah.
Pembelajaran bahasa Indonesia di sekolah dasar diarahkan untuk meningkatkan kemampuan peserta didik untuk berkomunikasi dalam bahasa Indonesia dengan baik dan benar, baik secara lisan maupun tulis, serta menumbuhkan apresiasi terhadap hasil karya kesastraan manusia Indonesia.

Bahasa Indonesia tidak semata diajarkan sebagai ilmu pengetahuan tetapi dipraktikkan sebagai penghela ilmu pengetahuan. Hal ini dilakukan karena Kurikulum 2013 dirancang untuk menyongsong model pembelajaran abad 21, yang di dalamnya terdapat pergeseran dari siswa diberi tahu menjadi siswa mencari tahu dari berbagai sumber belajar melampaui batas pendidik dan satuan pendidikan. Karenanya peran bahasa menjadi sangat sentral. Menurut Mahsun (2014, hlm.94), penempatan bahasa Indonesia 
sebagai penghela ilmu pengetahuan disamping memberi penegasan akan pentingnya kedudukan bahasa Indonesia sebagai bahasa nasional yang mempersatukan berbagai etnis yang berbeda latar belakang bahasa lokal dan kedudukannya sebagai bahasa resmi Negara, juga menjadi langkah awal dalam mewujudkan hajat para pendiri bangsa yang mengumandangkan bahasa Indonesia sebagai bahasa ilmu pengetahuan. Karenanya bahasa Indonesia harus berada di depan semua mata pelajaran lain. Pembelajaran bahasa Indonesia memiliki peranan yang sangat penting bukan hanya untuk membina keterampilan komunikasi melainkan juga untuk kepentingan penguasaan ilmu pengetahuan. Mengingat fungsi penting pembelajaran bahasa, sudah selayaknya pembelajaran bahasa di sekolah dilaksanakan dengan sebaikbaiknya.

Berdasarkan observasi yang dilakukan di SD Negeri Serang 5 Kota Serang, khususnya kelas V, kemampuan siswa dalam menulis karangan narasi dapat disimpulkan masih rendah. Hal ini diperkuat dengan hasil wawancara dengan guru dan juga siswa. Diketahui bahwa siswa mengalami kesulitan dalam menuangkan ide, meruntutkan isi cerita, dan menyusun kalimat. Siswa juga mengalami kesulitan dalam menggunakan ejaan bahasa Indonesia yang tepat.

Aspek pembelajaran bahasa di Sekolah Dasar yang memegang peranan penting adalah pembelajaran menulis. Tanpa memiliki kemampuan menulis yang memadai sejak dini, anak akan mengalami kesulitan belajar di kemudian hari. Kemampuan menulis menjadi dasar utama, tidak saja bagi pembelajaran bahasa itu sendiri, tetapi juga bagi pembelajaran mata pelajaran lainnya. Menulis secara formal mulai dipelajari ketika duduk di bangku sekolah dasar. Di sekolah pelajaran menulis diarahkan untuk meningkatkan kemampuan mereka untuk berkomunikasi dalam bahasa Indonesia yang baik dan benar, secara lisan dan tertulis, dan untuk menumbuhkan apresiasi terhadap hasil karya kesastraan indonesia (Saleh dalam Soni, 2016)

Kemampuan menulis cerita narasi dipengaruhi oleh beberapa faktor. Pada prinsipnya faktor tersebut dikategorikan menjadi dua, yaitu faktor faktor internal dan factor 
eksternal. Faktor internal berasal dalam dirinya sendiri, hal ini berkaitan dengan pemahaman terhadap mekanik tulisan, misalnya pemahaman tentang sistem ejaan, kemudian sikap terhadap bahasa Indonesia. Faktor eksternal meliputi sarana dan prasarana yang mendukung aktivitas menulis, misalnya keberadaan buku-buku di perpustakaan. Sikap yang menyepelekan pelajaran bahasa Indonesia karena merasa sudah dapat berbicara dengan lancar serta kekurangpahaman akan kaidah ejaan membuat siswa kesulitan menuangkan idenya, sulit menyusun dan merangkai kata, serta sulit menggunakan variasi kalimat dalam menulis karangan sehingga karangan yang dihasilkan menjadi tidak beraturan. Beberapa penelitian yang mengungkapkan bahwa kemampuan siswa menulis masih rendah. Hal tersebut disebabkan karena berbagai faktor. Basri, (dalam Akib, 2016) mengemukakan faktor tersebut antara lain: (1) pokok bahasan menulis tidak memperoleh perhatian serius dari guru dan motivasi siswa dalam menulis sangat minim dan (2) sarana dan metode/strategi pembelajaran menulis belum efektif.
Berdasarkan latar belakang tersebut, maka masalah dalam penelitian ini dirumuskan sebagai berikut: 1) apakah terdapat hubungan sikap bahasa dengan kemampuan menulis narasi pada siswa kelas $\mathrm{V}$ SD Negeri Serang 5 Kota Serang; 2) apakah terdapat hubungan pengetahuan Ejaan Bahasa Indonesia (EBI) dengan kemampuan menulis narasi pada siswa kelas $\mathrm{V}$ SD Negeri Serang 5 Kota Serang; dan 3) apakah terdapat hubungan sikap bahasa dan pengetahuan Ejaan Bahasa Indonesia (EBI) secara bersama-sama dengan kemampuan menulis cerita narasi pada siswa kelas V SD Negeri Serang 5 Kota Serang. Tujuan penelitian ini adalah untuk mengetahui secara empirik hubungan antara sikap bahasa siswa dan pengetahuan Ejaan Bahasa Indonesia (EBI) dengan kemampuan menulis narasi siswa keas $V$ SD Negeri Serang 5 Kota Serang.

Menurut Nuryatin (dalam Ahsin, 2016) narasi merupakan sebuah karya yang didalamnya terkandung berbagai aspek tentang rangkaian cerita yang membentuk makna. Seorang pembaca cerita narasi kebanyakan akan terinspirasi dari sifat maupun kehidupan tokoh yang 
ia baca. Tidak sedikit dari mereka juga akan meniru kehidupan maupun sikap tokoh yang mereka kagumi dalam sebuah narasi. Menulis narasi bisa berdasarkan pengalaman. Pengalaman mencakupi pengalaman fisik dan pengalaman nonfisik.Narasi adalah rangkaian tuturan yang menceritakan atau menyajikan suatu hal kejadian melalui tokoh atau pelaku dengan maksud memperluas pengetahuan pendengar atau pembaca (A.S. Syamsuri dan M.A. Muhsin, 2016).

De Porter dan Hernacki (2000, hlm.14) menyatakan bahwa kemampuan adalah keterampilan dalam menguasai sesuatu. Dalam hal ini berarti kemampuan perlu dilatih secara berulang-ulang agar semakin menguasai suatu kegiatan tertentu. Selanjutnya, berdasarkan pendapat tersebut maka dapat disimpulkan bahwa kemampuan menulis narasi adalah kesanggupan menuangkan ide dan gagasan dalam bentuk karangan untuk menceritakan urutan sebuah kejadian.

Gagne (1989, hlm. 85) menyatakan bahwa sikap adalah suatu ungkapan internal yang menunjukkan perasaan pilihan seseorang atas tindakan terhadap objek orang atau kejadian. Dengan kata lain, sikap adalah kecondongan yang menyenangkan atau tidak menyenangkan terhadap objek sosial seperti orang, tempat, dan kebijaksanaan. Howars dan Kendler (St. Nujraeni dkk., 2015) mengemukakan bahwa sikap berhubungan dengan aspek motivasi, perasaan, dan emosi. Oleh karena itu,sikap bahasa akan menghasilkan kecenderungan positif atau negatif. Berdasarkan definisi tersebut terlihat bahwa sikap setiap individu berbedabeda setiap orang dan merupakan sesuatu yang asli dari pembawaan orang. Berdasarkan beberapa pendapat tersebut dapat disimpulkan bahwa sikap bahasa siswa adalah kecenderungan untuk bereaksi terhadap bahasa Indonesia, baik senang ataupun tidak senang.

Ejaan adalah keseluruhan peraturan bagaimana melambangkan bunyi ujaran dan bagaimana antarhubungan antara lambinglambang itu (pemisahan dan penggambungannya dalam suatu bahasa). Secara teknis, yan $g$ dimaksud dengan ejaan ialah penulisan huruf, penulisan kata, dan pemakaian tanda baca (Arifin dan Tasai, 2008, hlm. 164). Kridalaksana 
(2008, hlm. 48) mengemukakan bahwa ejaan merupakan penggambaran bunyi bahasa dengan kaidah tulis-menulis yang distandarisasikan, yang lazim memiliki tiga aspek yani aspek fonologis yang menyangkut penggambaran fonem dengan huruf dan penyusunan abjad, aspek morfologis yang menyangkut penggambaran satuan-satuan morfemis, dan aspek sintaksis yang menyangkut penanda ujaran berupa tanda baca. Dari beberapapendapat tersebut dapat disimpulkan bahwa pengetahuan Ejaan Bahasa Indonesia (EBI) adalah kesanggupan mengetahui kaidah-kaidah Ejaan Bahasa Indonesia (EBI) yang tepat untuk penulisan karangan.

Hasil penelitian Soni (2015) di SD Inpres Mayayap Kecamatan Bualemo Kabupaten Banggai diperoleh informasi bahwa dalam pembelajaran menulis narasi berbagai kesulitan dan hambatan yang dihadapi siswa. Kesulitan dan hambatan tersebut adalah: (1) kesulitan dalam menemukan ide, (2) kesulitan dalam menuangkan ide, biasanya berawal dari ketidaktahuan siswa untuk menulis apa dan darimana memulai menuliskan berbagai ide yang terkandung dalam pikiran siswa. Sehingga sebagai siswa tidak dapat menuliskan ide pokok dalam buku sampai berakhirnya waktu, (3) kesulitan dalam mengembangkan ide, (4) kesulitan dalam merangkai kata atau kalimat dengan tepat, siswa terkadang merasa bahwa tulisannya tidak sesuai seperti yang diharapkan. Sehingga menimbulkan upaya penggantian kalimat. Selain itu di dalam menulis siswa keterkaitan antarkalimat dan antara paragrap kurang terlihat.

$$
\text { Penelitian Kamal }
$$
membuktikan bahwa terdapat hubungan yang signifikan antara ejaan dan tanda baca dengan kemampuan menulis karangan narasi. Hal itu disebabkan keterampilan menulis narasi menghendaki penguasaan berbagai unsur kebahasaan dan di luar bahasa itu sendiri yang akan menjadi isi karangan atau tulisan. Dari sisi kebahasaan khususnya pengetahuan tentang pengguaan ejaan sangat penting dikuasai oleh siswa. Selain itu dalam menulis juga terdapat aturan yang berlaku agar tulisan layak untuk dibaca oleh orang lain. Ide tulisan tidak akan datang tiba-tiba 
tanpa adanya pengetahuan yang dimiliki oleh penulis.

\section{B. METODE PENELITIAN}

Penelitian ini dilaksanakan pada siswa kelas V SD Negeri Serang 5 Kota Serang. Pelaksanaan penelitian selama 4 bulan dimulai dari Agustus sampai dengan November 2016. Jenis penelitian ini adalah penelitian survai dengan teknik korelasional. Populasi penelitian ini adalah seluruh siswa kelas V SD Negeri Serang 5 Kota Serang yang berjumlah 44 orang. Sampel diambil sebanyak 44 orang siswa dikarenakan jumlah populasi kurang dari 100 orang sesuai dengan pendapat Sugiono (2015, hlm.116) bahwa jika populasi kurang dari 100,maka diambil semua populasi. Instrumen pengumpulan data yang digunakan berupa tes menulis narasi berbentuk tes komposisi, tes pengetahuan Ejaan Bahasa Indonesia (EBI) berbentuk tes pilihan ganda, dan angket sikap bahasa.

Validitas tes menulis narasi menggunakan validitas konstruk, kemudian reliabilitasnya dengan reliabilitas rating. Validitas tes pengetahuan Ejaan Bahasa Indonesia (EBI) menggunakan rumus koefisien korelasi point biserial dan reliabilitasnya menggunakan rumus KR-20. Validitas angket sikap bahasa menggunakan rumus product moment dan reliabilitasnya menggunakan rumus Alpha Cronbach. Teknik analisis data yang digunakan meliputi uji persyaratan hipotesis dan uji hipotesis. Uji persyaratan meliputi uji normalitas data dan uji linearitas data. Uji hipotesis menggunakan menggunakan product moment karena mencari hubungan dan membuktikan hipotesis. Pengujian korelasi ini menggunakan bantuan SPSS 22.

\section{HASIL DAN PEMBAHASAN}

Penelitian ini terdiri atas tiga variabel yaitu dua variabel bebas dan satu variabel terikat. Variabel bebas dalam penelitian ini adalah sikap bahasa dan pengetahuan Ejaan Bahasa Indonesia (EBI), sedangkan variabel terikat adalah kemampuan menulis narasi.

Data kemampuan menulis narasi merupakan skor yang diperoleh siswa melalui tes menulis narasi. Data ini memiliki nilai tertinggi 90 dan nilai terendah 60. Mean (nilai rata-rata)-nya 71,16 , median data ini 
adalah 70, dan modus data ini adalah skor 62, kemudian dengan simpangan baku sebesar 8,29. Kecenderungan nilai variabel $Y$ dibagi menjadi tiga yaitu, tinggi, sedang, dan rendah. Data menunjukkan bahwa sebanyak 5 siswa $(12 \%)$ berada pada kategori tinggi, 23 siswa (52\%) berada pada kategori sedang, dan 16 siswa (36\%) berada pada kategori rendah.

Data sikap bahasa merupakan skor yang diperoleh siswa melalui angket sikap bahasa.. Data ini memiliki nilai tertinggi 92 dan nilai terendah 58. Mean (nilai rata-rata)nya 77 , median data ini adalah 78 , dan modus data ini adalah skor 86, kemudian dengan simpangan baku sebesar 9,19. Kecenderungan nilai variabel sikap bahasa dibagi menjadi tiga yaitu, tinggi, sedang, dan rendah. Data menunjukkan bahwa sebanyak
9 siswa (20\%) berada pada kategori tinggi, 28 siswa (64\%) berada pada kategori sedang, dan 7 siswa (16\%) berada pada kategori rendah.

Data pengetahuan Ejaan Bahasa Indonesia (EBI) merupakan skor yang diperoleh siswa melalui tes pengetahuan ejaan. Data ini memiliki nilai tertinggi 79 dan nilai terendah 48. Mean (nilai rata-rata)-nya 65,07 , median data ini adalah 67 , dan modus data ini adalah skor 70, kemudian dengan simpangan baku sebesar 7,65. Kecenderungan nilai variabel pengetahuan EBI dibagi menjadi tiga yaitu, tinggi, sedang, dan rendah. Data menunjukkan bahwa sebanyak 8 siswa (18\%) berada pada kategori tinggi, 31 siswa (71\%) berada pada kategori sedang, dan 5 siswa (11\%) berada pada kategori rendah.

Tabel 1 Rangkuman Deskripsi data

\begin{tabular}{|l|c|l|c|l|c|}
\hline \multicolumn{5}{|c|}{ Variabel Y } & \multicolumn{2}{c|}{ Variabel X1 } & \multicolumn{2}{c|}{ Variabel X2 } \\
\hline Skor Tertinggi & 90 & Skor Tertinggi & 92 & Skor Tertinggi & 79 \\
\hline Skor Terendah & 60 & Skor Terendah & 58 & Skor Terendah & 48 \\
\hline Mean & 71,16 & Mean & 77 & Mean & 65,07 \\
\hline Median & 70 & Median & 78 & Median & 67 \\
\hline Modus & 62 & Modus & 86 & Modus & 70 \\
\hline Simpangan Baku & 8,29 & Simpangan Baku & 9,19 & Simpangan Baku & 7,65 \\
\hline \multicolumn{2}{|c|}{ Kategorisasi Variabel Y } & \multicolumn{2}{|c|}{ Kategorisasi Variabel X1 } & \multicolumn{2}{c|}{ Kategorisasi Variabel X2 } \\
\hline
\end{tabular}


Pendas : Jurnal IImiah Pendidikan Dasar, ISSN Cetak : 2477-2143 ISSN Online : 2548-6950 Volume II Nomor 1, Juni 2017

\begin{tabular}{|l|c|l|c|l|c|} 
Tinggi & $5(12 \%)$ & Tinggi & $9(20 \%)$ & Tinggi & $8(18 \%)$ \\
\hline Sedang & $23(52 \%)$ & Sedang & $28(64 \%)$ & Sedang & $\begin{array}{c}31 \\
(71 \%)\end{array}$ \\
\hline Rendah & $16(36 \%)$ & Rendah & $7(16 \%)$ & Rendah & $5(11 \%)$ \\
\hline
\end{tabular}

Uji persyaratan analisis dalam penelitian ini meliputi uji normalitas, uji linearitas, serta uji kolinearitas. Karakteristik data penelitian yang telah dikumpulkan sangat menentukan teknik analisis yang digunakan. Oleh karena itu, sebelum analisis data secara inferensial untuk kepentingan pengujian hipotesis dilakukan, terlebih dahulu data-data tersebut perlu diadakan pemeriksaan atau diuji. Pengujian yang dilakukan menyangkut (1) pengujian normalitas, (2) pengujian linearitas, dan pengujian multikolinearitas. Uraian berikut ini mengetengahkan hasil pengujian tersebut.

Uji normalitas data dilakukan dengan mempergunakan teknik Lilliefors (Sudjana, 2006, hlm. 466467). Pengujian normalitas terhadap data kemampuan menulis narasi $(Y)$ menghasilkan Lo maksimum sebesar 0,042 . Dari daftar nilai kritis $L$ untuk uji Lilliefors dengan $n=44$ dan taraf nyata $\alpha=0,05$ diperoleh $L t=0,130$. Dari perbandingan di atas tampak bahwa $L o(0,042)$ lebih kecil daripada Lt $\quad(0,130) \quad$ sehingga dapat disimpulkan bahwa data kemampuan menulis narasi $(\mathrm{Y})$ berasal dari populasi yang berdistribusi normal.

Pengujian normalitas terhadap data sikap bahasa menghasilkan Lo maksimum sebesar 0,063 . Dari daftar nilai kritis $L$ untuk uji Lilliefors dengan $n=44$ dan taraf nyata $\alpha=0,05$ diperoleh $L t=0,130$. Dari perbandingan di atas tampak bahwa $L o(0,063)$ lebih kecil daripada Lt $(0,130)$ sehingga dapat disimpulkan bahwa data sikap bahasa (X1) berasal dari populasi yang berdistribusi normal.

Pengujian normalitas terhadap data pengetahuan Ejaan Bahasa Indonesia (X2) menghasilkan Lo maksimum sebesar 0,120 . Dari daftar nilai kritis $L$ untuk uji Lilliefors dengan $\mathrm{n}=44$ dan taraf nyata $\alpha=$ 0,05 diperoleh $L t=0,130$. Dari perbandingan di atas tampak bahwa Lo $(0,120)$ lebih kecil daripada $L t$ $(0,130)$, sehingga dapat disimpulkan bahwa data pengetahuan Ejaan Bahasa Indonesia (X2) berasal dari populasi yang berdistribusi normal. 
Hasil uji linieritas di atas menunjukkan bahwa Fhitung $>$ Ftabel yaitu pada variabel sikap bahasa $(0,876>0,622)$ dan signifikansi sebesar $0,000<0,05$, sedangkan pada variabel pengetahuan Ejaan Bahasa Indonesia $(1,084>0,430)$ dan signifikansi $0,000<0,05$, sehingga kedua variabel tersebut dapat dikatakan linier.

Uji multikolinieritas dalam penelitian ini dimaksudkan untuk mengetahui apakah terjadi multikolinieritas antarvariabel bebas. Uji multikolinieritas menuntut bahwa antara variabel bebas tidak boleh ada korelasi yang sangat tinggi, yaitu harga rhitung lebih besar dari 0,800.
Untuk menguji multikolinieritas mengunakan korelasi product moment guna menghitung korelasi antarvariabel bebas yang satu dengan variabel bebas yang lain. $\mathrm{Uji}$ multikolinieritas dilakukan sebagai syarat digunakannya analisis korelasi Product Moment dari Karl Person. Berdasarkan hasil uji multikolinieritas antarvariabel menunjukkan bahwa interkorelasi antarvariabel sebesar 0,763. Dari hasil tersebut, maka dapat disimpulkan bahwa hasil interkorelasi antarvariabel bebas tidak melebihi 0,800. Dengan demikian tidak terjadi multikolinieritas, maka analisis korelasi ganda dapat digunakan.

Tabel 2 Rangkuman Uji Persyaratan Analisis

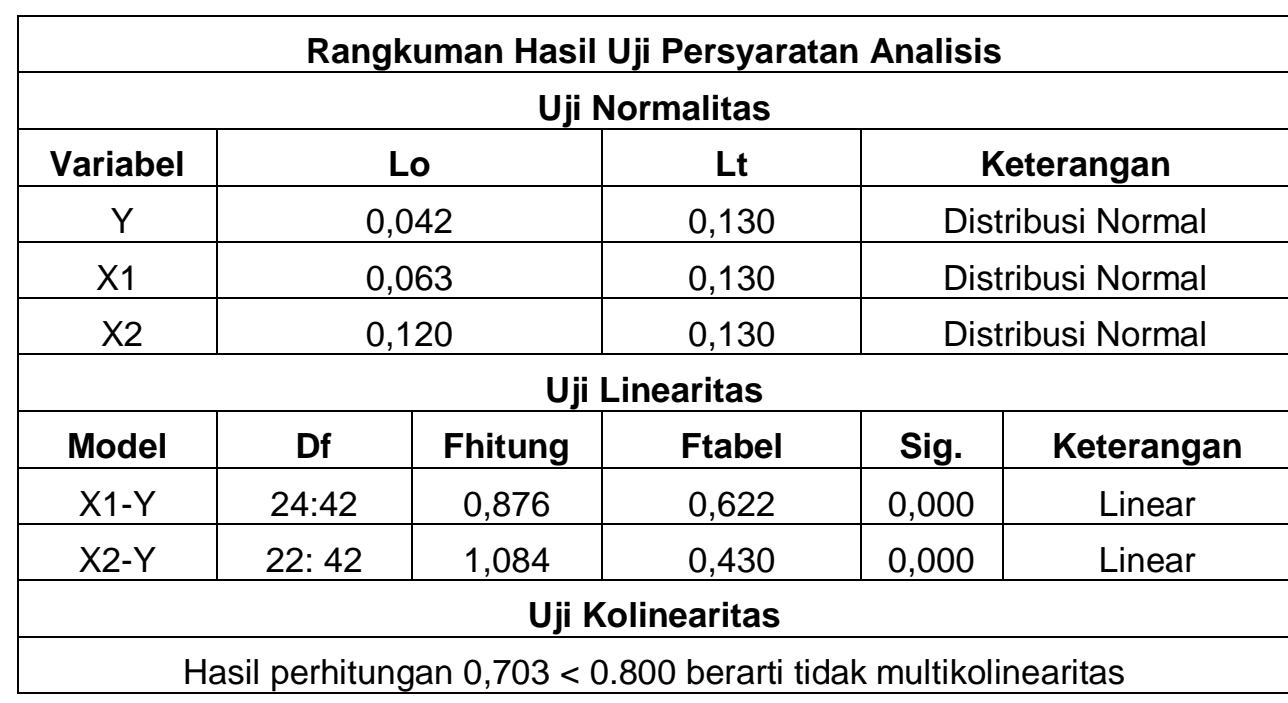

\section{Pengujian Hipotesis}

Hipotesis pertama menyatakan bahwa terdapat hubungan positif dan signifikan antara sikap bahasa (X1) dengan kemampuan menulis narasi $(Y)$. Analisis data menggunakan 
SPSS 22 menunjukkan bahwa tingkat kesalahan hasil perhitungan variabel sikap bahasa (X1) dengan kemampuan menulis narasi $(\mathrm{Y})$ sebesar 0,00 pada taraf kesalahan $5 \%$. Hasil tersebut menunjukkan bahwa nilai $p 0,00$ lebih kecil dari nilai kesalahan $0,05 \quad(0,00<0,05)$. Selain itu, pengujian dapat pula dilakukan menggunakan perbandingan antara rhitung dengan rtabel pada taraf kesalahan $5 \%$. Apabila nilai rhitung lebih besar dari nilai rtabel maka korelasi tersebut signifikan, sebaliknya jika nilai rhitung lebih kecil dari nilai rtabel maka korelasi tersebut tidak signifikan. Pengolahan data menunjukkan bahwa koefisien hubungan (rx1y) sikap bahasa dengan kemampuan menulis narasi (Y) siswa kelas V SD Negeri Serang 5 Kota Serang sebesar 0,586. Untuk mengetahui apakah pengaruh tersebut signifikan atau tidak, dengan membandingkan nilai rhitung dengan nilai rtabel pada taraf kesalahan $5 \%$ dan $\mathrm{n}=44$ sebesar 0,245. Hasil koefisien korelasi (rx1y) menunjukkan bahwa rhitung lebih besar daripada rtabel $(0,586>0,245)$ maka terdapat hubungan yang signifikan. Jadi hipotesis yang diajukan diterima. Oleh karena itu, hasil penelitian ini adalah terdapat hubungan yang positif dan signifikan antara sikap bahasa dengan kemampuan menulis narasi pada siswa kelas V SD Negeri Serang 5 Kota Serang.

Hipotesis kedua menyatakan bahwa terdapat hubungan positif dan signifikan antara pengetahuan Ejaan Bahasa Indonesia (X2) dengan kemampuan menulis narasi $(\mathrm{Y})$. Analisis data menunjukkan bahwa tingkat kesalahan hasil perhitungan variable pengetahuan Ejaan Bahasa Indonesia (X2) dengan kemampuan menulis cerita narasi $(\mathrm{Y})$ sebesar 0,00 pada taraf kesalahan $5 \%$. Hasil tersebut menunjukkan bahwa nilai $p$ 0,00 lebih kecil dari nilai kesalahan $0,05 \quad(0,00<0,05) . \quad K e m u d i a n$, pengujian dapat pula dilakukan menggunakan perbandingan antara rhitung dengan rtabel pada taraf kesalahan $5 \%$. Apabila nilai rhitung lebih besar dari nilai rtabel maka korelasi tersebut signifikan, sebaliknya jika nilai rhitung lebih kecil dari nilai rtabel maka korelasi tersebut tidak signifikan. Pengolahan data menunjukkan bahwa koefisien hubungan (rx2y) pengetahuan Ejaan Bahasa Indonesia (X2) dengan kemampuan menulis narasi $(\mathrm{Y})$ siswa sebesar 0,680. Untuk 
mengetahui apakah pengaruh tersebut signifikan atau tidak, dengan membandingkan nilai rhitung dengan nilai rtabel pada taraf kesalahan $5 \%$ dan $n=44$ sebesar 0,245. Hasil koefisien korelasi (rx2y) menunjukkan bahwa rhitung lebih besar daripada rtabel $(0,680>0,245)$ maka terdapat hubungan yang signifikan. Jadi hipotesis yang diajukan diterima. Oleh karena itu, hasil penelitian ini adalah terdapat hubungan yang positif dan signifikan antara pengetahuan Ejaan Bahasa Indonesia dengan kemampuan menulis narasi pada siswa kelas $\mathrm{V}$ SD Negeri Serang 5 Kota Serang.

Hipotesis yang ketiga adalah terdapat hubungan yang positif dan signifikan antara sikap siswa bahasa (X1) dan pengetahuan Ejaan Bahasa Indonesia (X2) secara bersama-sama dengan kemampuan menulis narasi (Y). Pengujian hipotesis ini menggunakan analisis korelasi ganda yang menunjukkan hubungan sikap bahasa (X1) dan pengetahuan Ejaan Bahasa Indonesia (X2) dengan kemampuan menulis narasi $(\mathrm{Y})$ diperoleh dari $R$ square sebesar 0,718. Kemudian Rtabel sebesar 0,516. Pengujian ini bertujuan untuk mengetahui signifikansi korelasi sikap bahasa (X1) dan pengetahuan Ejaan Bahasa Indonesia (X2) dengan kemampuan menulis narasi $(Y)$. Hasil perhitungan menunjukkan Rhitung $(0,718)$ lebih besar daripada Rtabel (0,516). Berdasarkan hasil uji diperoleh nilai $P$ value sebesar 0,000 lebih kecil dari 0,05. Kesimpulannya adalah bahwa sikap bahasa (X1) dan pengetahuan Ejaan Bahasa Indonesia (X2) memiliki hubungan yang positif dan signifikan secara bersama-sama dengan kemampuan menulis narasi $(Y)$ pada siswa kelas V SD Negeri Serang 5 Kota Seran

\section{Tabel 3 Rangkuman Uji Hipotesis}

\begin{tabular}{|c|c|c|c|}
\hline \multicolumn{4}{|c|}{ Rangkuman Hasil Uji Hipotesis } \\
\hline \multicolumn{4}{|c|}{ Korelasi Sederhana } \\
\hline Model & r-hitung & r-tabel & Keterangan \\
\hline X1 - Y & 0,566 & 0,245 & Signifikan \\
\hline X2 - Y & 0,680 & 0,245 & Signifikan \\
\hline \multicolumn{4}{|c|}{ Korelasi Ganda } \\
\hline Model & R-hitung & R-tabel & Keterangan \\
\hline$(X 1, X 2)-Y$ & 0,718 & 0,516 & Signifikan \\
\hline
\end{tabular}




\section{Pembahasan}

Penelitian ini bertujuan untuk mengetahui secara empirik hal-hal sebagai berikut: 1) hubungan sikap bahasa dengan kemampuan menulis narasi pada siswa kelas V SD Negeri Serang 5 Kota Serang; 2) hubungan pengetahuan Ejaan Bahasa Indonesia (EBI) dengan kemampuan menulis narasi pada siswa kelas $\mathrm{V}$ SD Negeri Serang 5 Kota Serang; dan 3) hubungan sikap bahasa dan pengetahuan Ejaan Bahasa Indonesia (EBI) secara bersamasama dengan kemampuan menulis narasi pada siswa kelas V SD Negeri Serang 5 Kota Serang. Berdasarkan data penelitian yang dianalisis, maka dilakukan pembahasan tentang hasil penelitian sebagai berikut.

Hasil penelitian ini membuktikan hipotesis pertama yaitu terdapat hubungan yang positif dan signifikan antara sikap bahasa dengan kemampuan menulis narasi pada siswa kelas V SD Negeri Serang 5 Kota Serang diterima.

Sikap adalah kecenderungan untuk bereaksi terhadap suatu objek, baik senang ataupun tidak senang. Misalnya, seorang siswa yang menaruh sikap positif terhadap bahasa Indonesia akan memusatkan perhatian lebih banyak terhadap mata pelajaran bahasa Indonesia. Kecenderungan bersikap positif terhadap mata pelajaran bahasa Indonesia memungkinkan siswa untuk belajar lebih giat dan mencapai apa yang diinginkan.

Sikap positif terhadap bahasa Indonesia akan membuat siswa memusatkan perhatian sepenuh hati terhadap mata pelajaran. Hal ini sejalan dengan pendapat Djaali (2008, hlm.117) yang menegaskan bahwa sikap terhadap pembelajaran bukan saja sikap yang ditujukan kepada guru, melainkan juga kepada tujuan yang akan dicapai, materi pelajaran, tugas, dan lain-lain. Sikap siswa terhadap bahasa Indonesia akan terwujud dalam bentuk perasaan senang atau tidak senang, setuju atau tidak setuju, suka atau tidak suka terhadap komponen sikap. Sikap seperti ini akan berpengaruh terhadap proses dan hasil belajar yang dicapainya. Sesuatu yang menimbulkan rasa senang, cenderung akan diulang. Rasa lebih suka dan rasa ketertarikan pada suatu hal akan mendorong siswa melakukan aktivitas belajar walaupun tidak ada yang menyuruh. Sikap merupakan potensi, pendorong 
dalam individu untuk bereaksi. Sikap seseorang terhadap objek adalah perasaan mendukung ataupun perasaan tidak mendukung pada objek tersebut.

Hasil penelitian membuktikan bahwa hipotesis kedua diterima. Berarti terdapat hubungan yang positif dan signifikan antara pengetahuan Ejaan Bahasa Indonesia (EBI) dengan kemampuan menulis narasi pada siswa kelas $\mathrm{V}$ SD Negeri Serang 5 Kota Serang. Hal ini mengandung makna bahwa makin baik penguasaan ejaan bahasa Indonesia, makin baik pula kemampuan menulis narasi mereka.

Kaidah ejaan menjadi salah satu aspek yang sangat berarti dalam hal menulis karangan narasi karena semua aspek kebahasaan akan selalu menggunakan kaidah ejaan di dalamnya. Pengetahuan terhadap ejaan merupakan aspek kebahasaan yang harus dikuasai. Adapun aspek ejaan yang dimaksud dalam penelitian ini adalah aspek penulisan huruf, penulisan kata,dan penggunaan tanda baca. Penguasaan kaidah ejaan menjadi dasar seorang terampil menuangkan gagasan dalam bentuk bahasa tertulis. Seorang siswa dituntut untuk memiliki pengetahuan ejaan yang baik agar mahir dalam berbahasa. Oleh karena itu, dengan mengetahui kaidah Ejaan Bahasa Indonesia (EBI) diharapkan mampu mengembangkan daya dan pemahaman untuk menulis karangan narasi.

Hipotesis penelitian ketiga yang menyatakan ada hubungan positif sikap bahasa dan pengetahuan Ejaan Bahasa Indonesia (EBI) secara bersama-sama dengan kemampuan menulis karangan narasi, mengandung arti bahwa kedudukan kedua variabel bebas tersebut sebagai prediktor varians nilai kemampuan menulis karangan narasi tidak perlu diragukan lagi.

Dalam pembelajaran bahasa Indonesia, khususnya dalam hal menulis karangan narasi, sikap merupakan aspek yang tidak boleh diabaikan karena sikap dapat mempengaruhi sukses tidaknya proses pembelajaran. Dengan demikian, sikap positif terhadap bahasa Indonesia diperlukan demi berhasilnya pembelajaran menulis karangan narasi di sekolah. Semakin senang siswa terhadap mata pelajaran bahasa Indonesia maka akan terjadi interaksi yang mendalam antara siswa dengan materi pelajaran 
maupun dengan pengajar. Hal ini memungkinkan terjadinya proses pembelajaran bahasa Indonesia, khusunya dalam hal pembelajaran menulis karangan narasi akan semakin baik.

Kaidah ejaan sangat diperlukan siswa ketika menuangkan gagasan dalam bentuk tertulis. Karangan narasi yang berupa menuangan gagasan secara tertulis dengan menggunakan alur yang teratur membutuhkan pengetahuan terhadap kaidah ejaan yang baik. Penulisan kata tugas misalnya sangat diperlukan karena narasi berkaitan dengan urutan waktu secara kronologis.

Dalam penelitian ini telah diupayakan penyusunannya sebaik mungkin. Dengan menggunakan metode ilmiah. Namun demikian, karena keterbatasan kemampuan peneliti tidak tertutup kemungkinan adanya kesalahan atau kekeliruan yang terdapat dalam hasil penelitian ini. Oleh karena itu, dalam penelitian ini perlu disampaikan beberapa keterbatasan penelitian.

Pertama, hasil penelitian ini hanya mengungkapkan kemampuan menulis narasi siswa yang berkaitan dengan variabel sikap bahasa siswa dan pengetahuan Ejaan Bahasa Indonesia (EBI) dengan populasi terbatas pada siswa kelas $\mathrm{V}$ SD Negeri Serang 5 Kota Serang. Oleh karena itu, generalisasi kesimpulan penelitian hanya dapat digunakan terhadap populasi yang memiliki karakteristik yang sama dengan populasi penelitian ini. Untuk mendapatkan hasil yang lebih komprehensif, wilayah populasi perlu diperluas. Dengan demikian diharapkan akan diperoleh informasi yang lebih banyak mengenai kemampuan menulis karangan narasi siswa.

Kedua, sebagai penelitian survei yang sebagian datanya dikumpulkan dengan menggunakan kuesioner model skala Likert, instrumen penelitian semacam ini kurang mampu menjangkau aspekaspek kualitatif dari indikator-indikator yang diukur. Untuk mengatasi hal itu, sebenarnya sudah diupayakan oleh peneliti dengan jalan menghimbau pada siswa agar memberikan jawaban yang sejujurnya.

Ketiga, instrumen bukan instrumen yang baku, tetapi dibuat sendiri oleh peneliti. Kemudian untuk mengetahui kesahihannya dan keterandalannya dilakukan uji coba 
instrumen. Ada kemungkinan masih banyak indikator yang tidak tersentuh dalam pembuatan instrumen ini.

\section{SIMPULAN}

Simpulan hasil penelitian ini terdapat hubungan positif sikap bahasa dan pengetahuan Ejaan Bahasa Indonesia (EBI) secara bersama-sama dengan kemampuan menulis narasi.

Pertama, terdapat hubungan yang positif sikap bahasa dengan kemampuan menulis karangan narasi. Artinya makin tinggi sikap bahasa, makin tinggi pula kemampuan menulis narasi mereka. $\mathrm{Hal}$ ini dibuktikan dengan hasil koefisien korelasi (rx1y) menunjukkan bahwa rhitung lebih besar daripada rtabel $(0,586>0,245)$ maka terdapat hubungan yang signifikan.

Kedua, terdapat hubungan yang positif dan signifikan antara pengetahuan Ejaan Bahasa Indonesia (EBI) dengan kemampuan menulis narasi pada siswa kelas $\mathrm{V}$ SD Negeri Serang 5 Kota Serang. Hal ini mengandung makna bahwa makin baik pengetahuan Ejaan Bahasa Indonesia (EBI), makin baik pula kemampuan menulis narasi mereka. Hal ini dibuktikan dengan hasil koefisien korelasi (rx2y) menunjukkan bahwa rhitung lebih besar daripada rtabel $(0,680>0,245)$ maka terdapat hubungan yang signifikan.

Ketiga, sikap bahasa (X1) dan pengetahuan Ejaan Bahasa Indonesia (X2) secara bersamasama memiliki hubungan yang positif dan signifikan dengan kemampuan menulis narasi $(Y)$. Hal ini dibuktikan dengan hasil koefisien korelasi (Rx1x2-y) menunjukkan bahwa rhitung lebih besar daripada rtabel $(0,718>0,516)$ maka terdapat hubungan yang signifikan. mengandung arti bahwa kedudukan kedua variabel bebas tersebut sebagai prediktor varians nilai kemampuan menulis narasi tidak perlu diragukan lagi.

\section{DAFTAR PUSTAKA}

Ahsin, Muhamad Nur.(2016). Peningkatan Keterampilan Menulis Karangan Narasi Dengan Menggunakan Media Audiovisual Dan Metode Quantum Learning . Jurnal Refleksi Edukatika.158-171.

Akib, Tasrif. (2016). Peningkatan Kemampuan Menulis Karangan Narasi Melalui Penerapan Pembelajaran Cooperative Integrated Reading And Competition (CIRC) Pada Siswa Kelas IV SD Inpres Panggentungan Selatan 
Kecamatan Somba Opu

Kabupaten Gowa. Konfiks: Jurnal Bahasa, Sastra, Dan Pengajaran.116-129.

Arifin, E. Zaenal dan S. Amran Tasai.(2008). Cermat Berbahasa Indonesia di Perguruan Tinggi. Jakarta: Akademi Pressindo.

A.S. Syamsuri dan M.A. Muhsin (2016). The Effectiveness of Caricature Media in Learning Writing of Argumentation Paragraph. Journal Theory and Practice in Language Studies. 7079.

De Porter, Bobby dan Mike Hernacki. (2000). Quantum Learning. Bandung: Kaifa.

Djaali. (2008). Psikologi Pendidikan. Jakarta: Bumi Aksara.

Gagne, Robert M. (1989). Kondisi Belajar dan Teori Pembelajaran. Diterjemahkan oleh Munandar. Jakarta: Depdikbud.

Kamal, Fatimah Sarah.(2016). Hubungan Ejaan dan Tanda Baca dengan Kemampuan Menulis Karangan Narasi Siswa Kelas XII SMA Negeri 1 Padangsidimpuan. Jurnal Kultura.125-132.
Kridalaksana, Harimurti. (2008). Kamus Linguistik. Jakarta: Gramedia.

Mahsun. (2014). Teks dalam Pembelajaran Bahasa Indonesia Kurikulum 2013. Jakarta: Rajagrafindo Persada.

Soni, Iranda B.(2015). Meningkatkan Kemampuan Siswa Kelas V SD Inpres Mayayap Dalam Menulis Karangan Narasi Melalui Model Pembelajaran Kooperatif .Jurnal Kreatif Tadulako Online. 53-61.

Sudjana, Nana.(2006). Penilaian Hasil Proses Belajar Mengajar. Bandung: Remaja Rosdakarya.

Sugiyono. (2015). Metode Penelitian Pendidikan. Bandung: Alfabeta.

St. Nujraeni dkk. (2015). The Attitudes and Behavior of Using Indonesian Language among the Bureaucrats in South Sulawesi Province. Journal of Language Teaching and Research. 778788. 